\title{
CLINICAL STUDIES OF THE BLOOD VOLUME. VI. CHANGES IN BLOOD VOLUME IN PERNICIOUS ANEMIA IN RELATION TO THE HEMATOPOIETIC RESPONSE TO INTRA- MUSCULAR LIVER EXTRACT THERAPY ${ }^{1}$
}

\author{
By JOHN G. GIBSON, 2D \\ (From the Medical Clinic of the Peter Bent Brigham Hospital and the Department of \\ Medicine, Harvard Medical School, Boston)
}

(Received for publication January 20, 1939)

The blood volume in pernicious anemia has been studied repeatedly by a variety of methods and all authors have commented upon the extremely low level of the total volume of circulating red cells found in the severe stages of this disease. There is less unanimity of opinion as regards the abnormality of both the plasma and total blood volume at various levels of anemia, the relationship between the severity of the disease and the degree of hypovolemia, and the changes in plasma, red cell, and total blood volume that occur during the course of successful liver therapy. Plasma volume was thought to be normal by Bock (1), Denny (2), and Murphy, et al. (3), or higher than normal, Keith (4), Rusynak (5), and De Wesselow and Bamforth (6). Denny (2) found no relation between the severity of the anemia and the total blood volume level, whereas Smith (7) noted that the total amount of hemoglobin was reduced in proportion to the severity of the disease. During treatment with liver the total blood volume was found to increase, due chiefly to a great increase in the red cell volume (6) which may be three or fourfold (3). The plasma volume was found to fall (6), during recovery, or increase (8), or remain fairly constant (3). Hölboll (8) could not find any relationship between the observed changes in the total blood volume and either the hematocrit or hemoglobin content of the blood, but De Wesselow and Bamforth (6) stated that the "increase in percentage of red cell volume and hemoglobin estimations gives an accurate index of the actual increase in red cell substance and hemoglobin during treatment."

\footnotetext{
1 This study together with those previously reported in a series of papers entitled "Clinical Studies of the Blood Volume. I to V," inclusive, published in the Journal of Clinical Investigation, were aided by a grant from the Proctor Fund for the Study of Chronic Diseases, Harvard Medical School.
}

It is evident that the current conception of the state of the blood volume during the various phases of pernicious anemia and the changes that take place during therapy is confused. It, therefore, seemed worth while to study the problem again, employing a dye method for determining the plasma and total blood volume in which the errors inherent in the techniques employed by the authors mentioned above are minimized $(9,10)$.

\section{MATERIAL STUDIED}

Six male and 4 female patients, in whom the diagnosis of pernicious anemia was made on the Medical Service or in the Blood Clinic of the Out-Door Department of the Peter Bent Brigham Hospital, were studied before and during the course of treatment with liver extract. All of these patients had hyperchromic anemia, high color index, gastric achlorhydria, and all experienced a marked rise in their reticulocyte count after treatment with liver extract. Initial blood volume studies were made before treatment was begun, at intervals during treatment with liver extract and, in 8 of the 10 cases, when the red blood cell count had reached a level of five million. Three of these patients were started on a single dose of extract ${ }^{2}$ derived from 600,500 , 400 , and 75 grams of liver $(60,50,40$, and 7.5 U.S.P. units) respectively, and 6 on small daily doses of concentrated extract, the total amount given in 10 daily doses being derived from 75 grams of liver (7.5 U.S.P. units) in 4 cases and 100 grams of liver (10 U.S.P. units) in 2 cases. Following the initial treatment, liver extract in amounts derived from 50 to 100 grams ( 5 to 10

\footnotetext{
2 Extracts used were Lederle "Solution Liver Extract Parenteral." The large single doses were of a preparation containing $10 \mathrm{U}$ U.S.P. units in $3 \mathrm{cc}$., the "concentrate" extract containing 15 U.S.P. units in $1 \mathrm{cc}$. of material. These extracts are said not to contain iron.
} 
U.S.P. units) of liver was given at intervals of from 7 to 12 days until the red count reached 5 million. Liver extract was given by intramuscular injection, and in no case was iron given, nor was liver given by mouth.

Plasma and total blood volumes and hematocrits were determined by methods previously described (10), venous pressures by a direct manometric method (11), circulation time by means of decholin (12), and hemoglobin content of venous blood by the method of Osgood and Haskins (13). Surface area was taken as the basis for the prediction of normal blood volume. Normal values for hematocrit were taken as 44 per cent and 40 per cent (14), for red blood cell counts as $5,480,000$ and $4,920,000$ cells per c.mm. of blood, and for hemoglobin content of venous blood as 16.03 and 14.21 grams per $100 \mathrm{cc}$. of whole blood (15), for men and women respectively. Based on the above, normal values were computed for mean corpuscular volume as $\mathbf{8 0 . 3}$ and 81.3 cubic microns, for mean corpuscular hemoglobin as 29.3 and 28.9 micrograms, and for mean corpuscular hemoglobin concentration as 36.5 and 35.5 grams per $100 \mathrm{cc}$. of packed red cells for men and women respectively. Total circulating hemoglobin was computed by multiplying the hemoglobin content in grams per $100 \mathrm{cc}$. of blood by the total blood volume in hundreds of cubic centimeters.

\section{RESULTS}

All of these patients made complete recoveries, the red blood cell count rising to about 5 million in from 40 to 60 days after the beginning of treatment. During the first 28 days of treatment the rate of recovery of individual patients varied somewhat as shown in Figure 1. During the first 10 days the response of 2 of the 3 patients (Cases 165,216 , and 283), receiving large initial doses, was more rapid than in those receiving small amounts of "concentrate" extract daily. Case 218 , receiving an initial single dose of material derived from 50 grams of liver (7.5 U.S.P. units), had a response comparable to those patients receiving divided doses of "concentrate" extract. The degree of recovery at 28 days, in terms of percentage of deficit from normal in red cell count existing before therapy, varied somewhat with the total dosage during this period but in general was proportionate to the amount of liver given.

\section{Blood volume}

The data obtained are presented in Table I. In Figure 2 are shown the absolute plasma, circulating red blood cell, and total blood volume at red blood cell count levels of from 1 to 5 million. Almost without exception at the initial determination, plasma volume was higher, and circulating red cell and total volume were lower than the average normal values (14) for men and women. In every case plasma volume fell and red cell and total blood volume rose as the red blood cell count increased to 5 million under liver therapy.

When recovery was complete, average plasma volume had decreased from initial levels by 473 cc. and $460 \mathrm{cc}$., average circulating red cell volume had increased by $1570 \mathrm{cc}$. and $1065 \mathrm{cc}$., and average total blood volume had increased by $928 \mathrm{cc}$. and $508 \mathrm{cc}$, in the males and females respectively. In no individual case was any marked deviation from the general trend observed. The increase in circulating red cell volume amounted to about 200 per cent and 150 per cent above the amount present before treatment was started in the males and females respectively.

In relation to normal blood volume predicted on the basis of surface area there was, at various levels of anemia, some individual variation in the percentage of deviation from normal in plasma, circulating red cell and total blood volume, the extremes of this variation being within about plus or minus 10 per cent of the average values for the group, which are shown in Figure 3. At a red blood cell count level of 1.5 million the plasma volume was 30 per cent above, the red cell volume 68 per cent below, and the total blood volume 16 per cent below normal. During recovery on liver therapy the fall in plasma volume and the rise in red cell and total blood volume were practically in linear relationship to the increase in the red blood cell count, and at the time the red blood cell count had reached 5 million, the plasma, circulating red cell, and total blood volume all were within normal limits. A similar relationship in the changes in plasma, circulating red cell, and total blood volume to the increase in the hematocrit level was observed. 


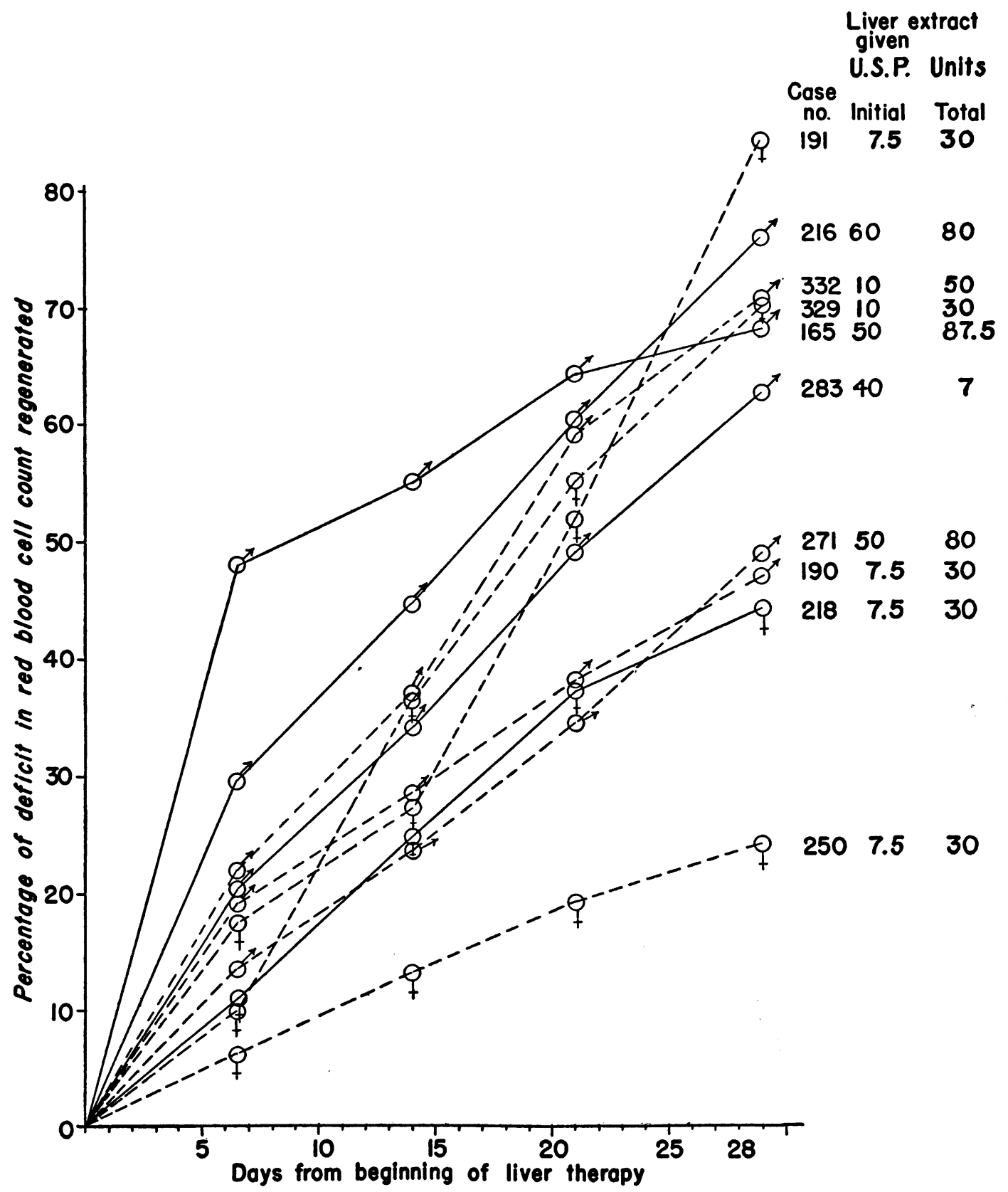

Fig. 1. The Course of the Red Blood Cell Count Expressed in Terms of Percentage of Initial Deficti Regenerated in 28 Days in 10 Cases of Pernicious Anemia Treated by IntramuscuLAR INJECTIONS OF LIVER EXTRACT

The amount of liver in U. S. P. units given as an initial dose and the total given during the period shown are listed opposite case numbers at the right. The solid lines represent the cases given large single initial doses and the broken lines the cases given 10 daily small doses of a concentrate extract. 


\begin{tabular}{|c|c|c|c|c|c|c|c|c|c|c|c|c|c|}
\hline \multirow{2}{*}{\multicolumn{2}{|c|}{ ॠ }} & & है है & 茎密品 & मुं & ชิสมี่ & 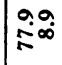 & 趈 & $\begin{array}{l}+400 \\
\text { मींदें }\end{array}$ & किज्ञ & 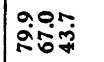 & 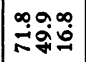 & ตัฒे \\
\hline & & & เป & & $\stackrel{\bullet}{\dot{m}}$ & & & $\hat{\infty}$ & $\vec{\infty}$ & & $\bar{i}$ & & $\stackrel{m}{i}$ \\
\hline a & \multicolumn{2}{|c|}{ 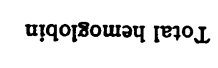 } & 参 & 유ำ & 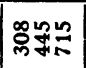 & ลูก์ & mo & 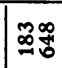 & 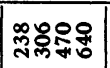 & 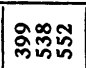 & 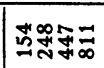 & 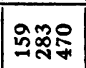 & 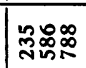 \\
\hline हี & \multicolumn{2}{|c|}{ 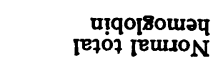 } & 峞 & 양요요 & ีํํํํำ & 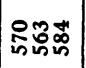 & 퓨곡 & นิ้ & $\mid$ & 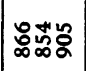 & 눗요뮤 & 总总号 & 안옷요 \\
\hline & \multirow{6}{*}{ 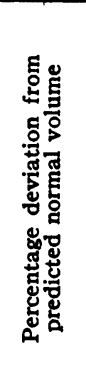 } & \multirow{2}{*}{ 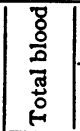 } & 해을 & $\vec{\Phi}$ & & & $\mid \underset{\sim}{\stackrel{4}{m}}$ & $\mid \frac{9}{4}$ & 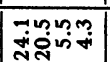 & 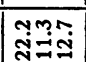 & 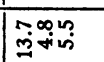 & 离 & $\operatorname{nug}_{\substack{\infty \\
\infty}}^{\infty}$ \\
\hline 8 & & & है हु & 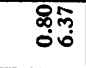 & 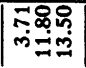 & | & & & & & $\stackrel{\circ}{\circ}$ & $\frac{n}{4}$ & $\stackrel{n}{3}$ \\
\hline & & \multirow{2}{*}{ 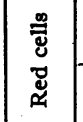 } & E्E & 我 & 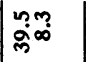 & نَّ & 点 & कीं & 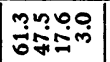 & 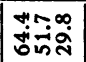 & 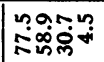 & $\mid$ & 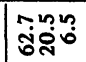 \\
\hline & & & के है & & $\stackrel{\circ}{\circ}$ & $n$ & $\circ$ & & & & & & \\
\hline & & \multirow{2}{*}{$\frac{\mathbb{E}}{\frac{\pi}{2}}$} & $\pm \vec{~}$ & & & & & $\stackrel{\infty}{\rightarrow+}$ & 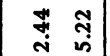 & & & & \\
\hline & & & \& & 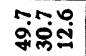 & $\mid$ & क⿺⿻一𠃋十 & |ูปส & 吕 & $\underset{i}{i} \stackrel{0}{i}$ & ปี్่สป - & 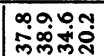 & 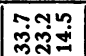 & 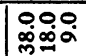 \\
\hline & \multirow{3}{*}{ 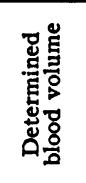 } & $\begin{array}{l}\text { poof| } \\
\text { pełoL }\end{array}$ & & 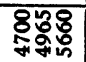 & 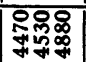 & $\mid$ & 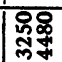 & ל్లిర్ల & 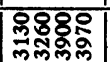 & 8 & 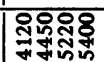 & 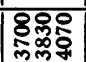 & 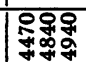 \\
\hline & & sІІ0 pay & & 앰점윰 & \&ర్రి: & 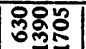 & 造 & 앙ㅇㅇ & 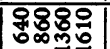 & 용요 & 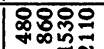 & 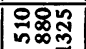 & 888 \\
\hline & & eurseld & & 앵융్ㅁ & 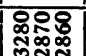 & 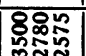 & 8ర웅 & 유웍 & 암웍엉유 & 윘윰윰 & 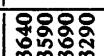 & 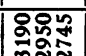 & 웅용 \\
\hline & \multirow{3}{*}{ 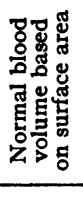 } & $\begin{array}{l}\text { poorq } \\
\text { [70工 }\end{array}$ & & 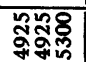 & 음유맘 & 앙్ㅇㅇㅠ. & 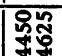 & 潒品 & 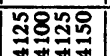 & 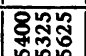 & 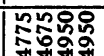 & กूก & ర్జిర్థి \\
\hline & & 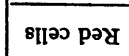 & & 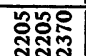 & 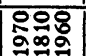 & 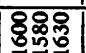 & 80 & 8 & 앵웅융융 & 닥역응 & 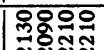 & 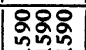 & 앙ㅇㅁ연 \\
\hline$\approx$ & & Eurseld & & 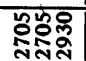 & 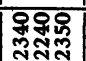 & $\mid$ & 多资 & 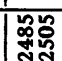 & 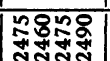 & कañ & 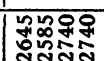 & 我 & 88: \\
\hline & \multicolumn{2}{|r|}{ 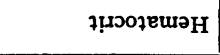 } & 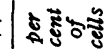 & 年 & $\mid$ & 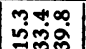 & $9=$ & 구요 & जिक्र & 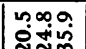 & "艹ำ7 & 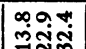 & :å0 \\
\hline & \multicolumn{2}{|r|}{ 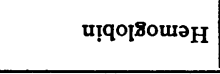 } & E & 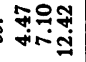 & 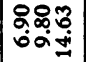 & $\mid$ & $\mid \begin{array}{l}\infty 8 \\
\infty \\
\text { ind }\end{array}$ & केष & | & | & mong & 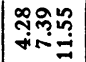 & فำ \\
\hline & \multicolumn{2}{|c|}{ sाг् pooाq pəy } & 艾: & هొ & 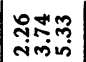 & 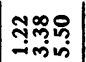 & تُّ & 象 & hึ? & 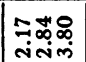 & 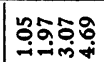 & 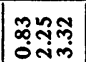 & 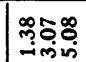 \\
\hline & \multicolumn{2}{|c|}{ 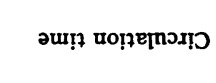 } & हू & শ્స & m゙ & คสก์ & maల & mజ & ニะテสล & ลిశి & ดปสกล & 표유 & 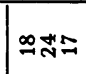 \\
\hline$\Sigma$ & \multicolumn{2}{|c|}{ วגnssədd snouว $\Lambda$} & 욤 & 촌 & 이아 & 으요 & $\operatorname{lin} 8$ & 2.6 & 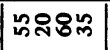 & \%๐ & 일 SP & mił & 내요 \\
\hline & \multicolumn{2}{|r|}{ вәге әэедй } & है. & ด्తి & 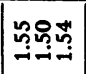 & 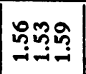 & نَత్రి & تُ & 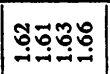 & 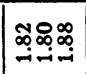 & | & 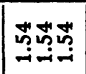 & \\
\hline & \multicolumn{2}{|r|}{$748 ! 9 M$} & 5 & 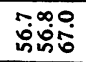 & mi:m & 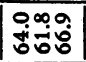 & |ूon & 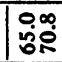 & 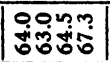 & 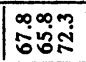 & 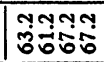 & 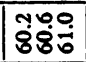 & | \\
\hline & \multicolumn{2}{|r|}{$748 \div 9 \mathrm{H}$} & $\varepsilon$ & 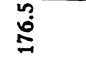 & : & 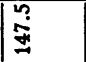 & 公 & $\mid$ & 它 & $\mid \begin{array}{l}n \\
\vdots \\
1 \\
\end{array}$ & 萬 & 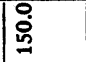 & 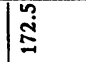 \\
\hline & \multicolumn{2}{|r|}{ ras } & & $\Sigma$ & $\Sigma$ & in & $\Sigma$ & is & is & $\Sigma$ & $\Sigma$ & in & $\Sigma$ \\
\hline & \multicolumn{2}{|r|}{$28 \mathrm{~V}$} & है & F & iि & $:$ & 8 & \% & 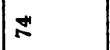 & $\approx$ & ? & 8 & 5 \\
\hline & & & 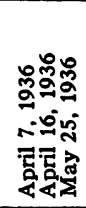 & 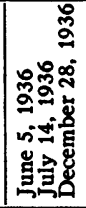 & 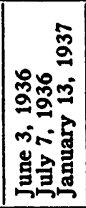 & 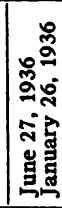 & 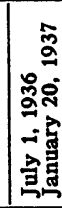 & 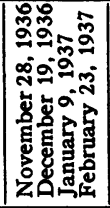 & 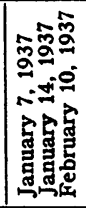 & 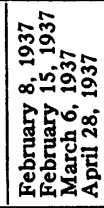 & 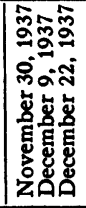 & 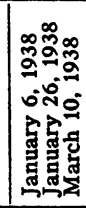 \\
\hline & \multicolumn{2}{|c|}{ 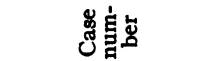 } & & 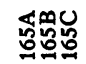 & ఫీయ & 迎行 & 倦是 & 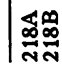 & 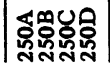 & 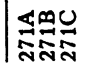 & 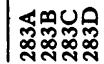 & 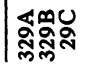 & 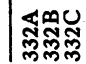 \\
\hline
\end{tabular}



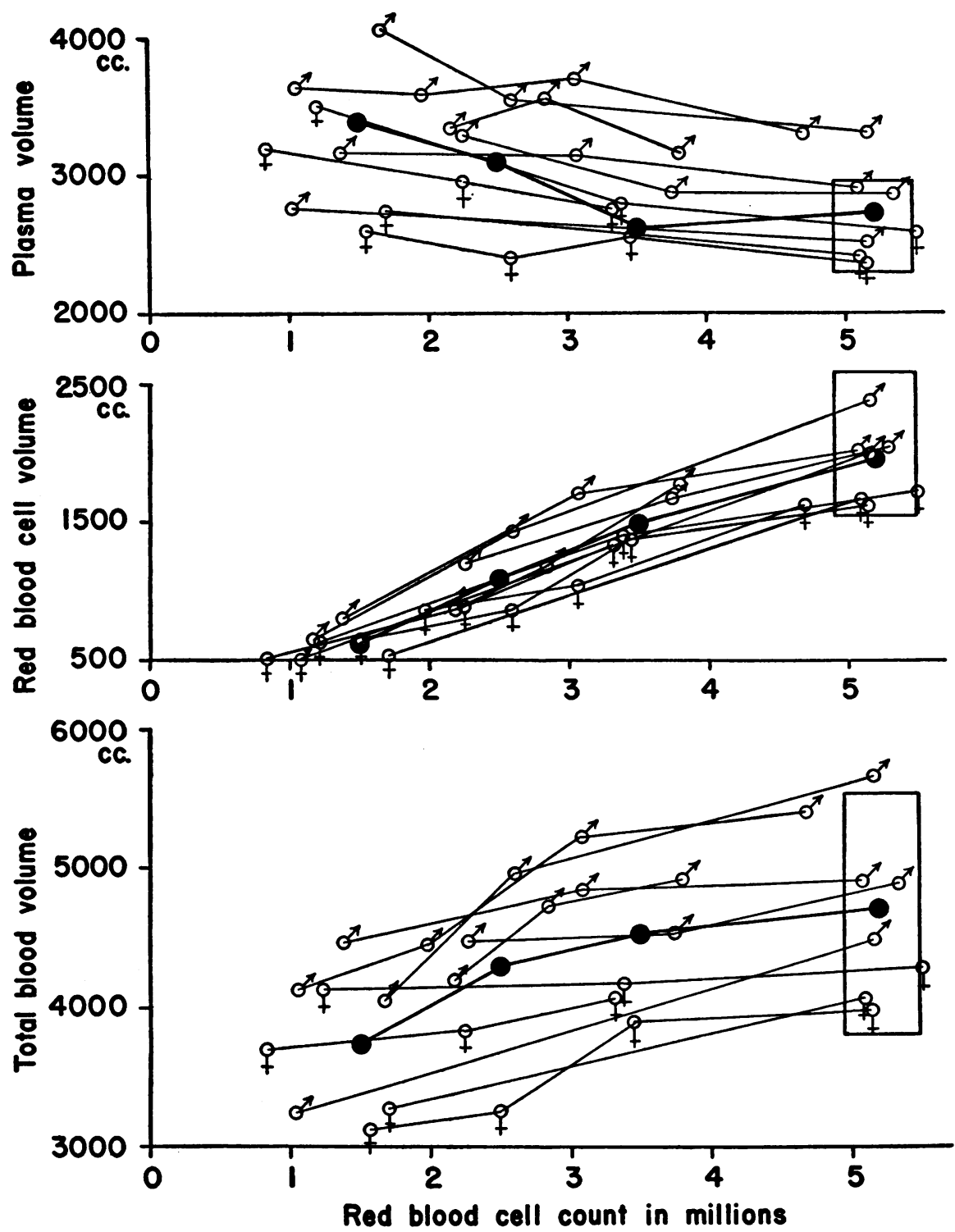

Fig. 2. Absolute Plasma, Circulating Red Celi, and Total Blood Volume in 10 Cases of Pernicious Anemia during Recovery on Intramuscular Liver Extract Therapy

The initial determinations were made just prior to the beginning of treatment. Normal limits are indicated by the rectangles at the right of the figure, the upper and lower borders representing the average normal volume levels, and the right and left borders representing the average normal red cell counts for males and females respectively. The heavy lines represent averages for the group. As the red cell count rises plasma volume diminishes, and circulating red cell and total blood volume increase, all returning to normal when the erythrocyte count reaches 5 million. 
JOHN G. GIBSON, 2D

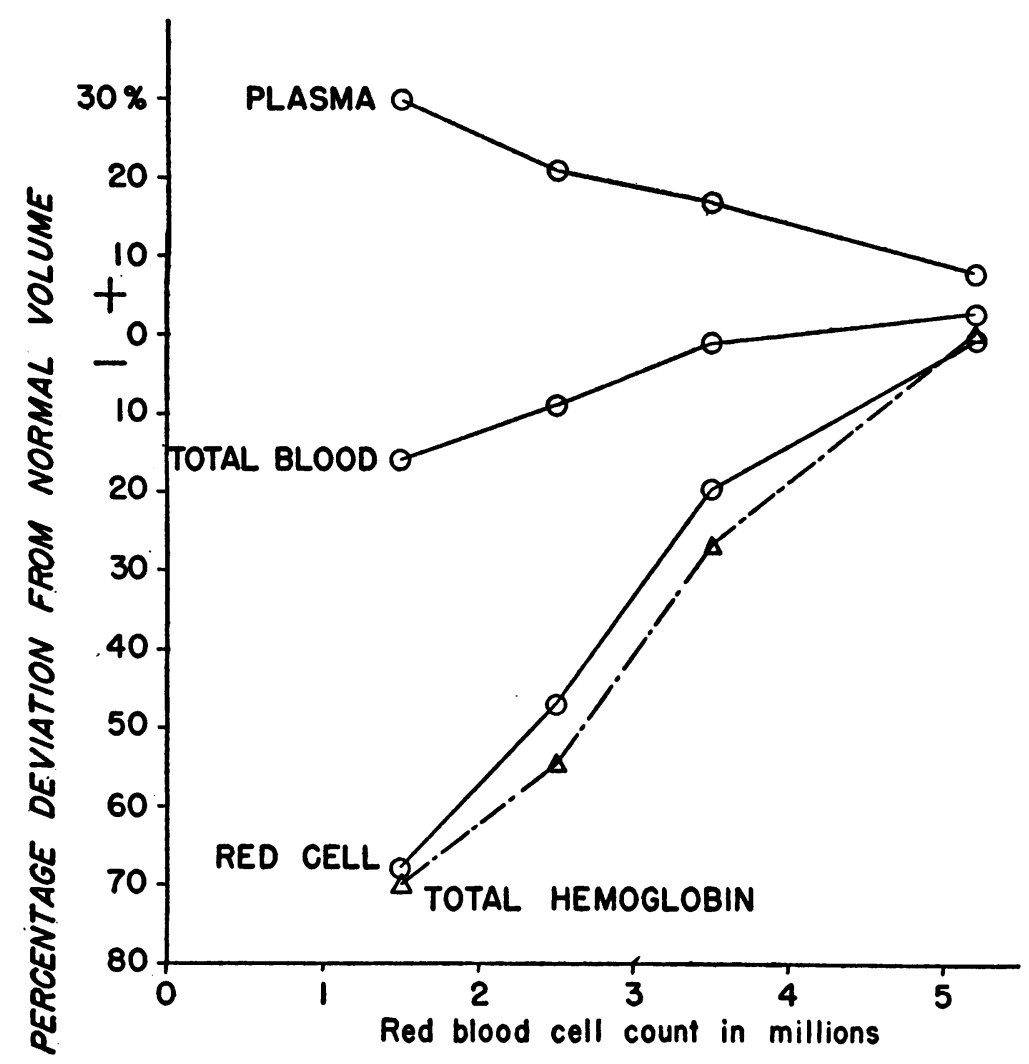

Fig. 3. The Percentage Deviation from Predicted Normal Values in Plasma, Circulating Red Cell and Total Blood Volume, and Total Circulating Hemoglobin in Severe Pernicious Anemia and during ReCOVERY ON LIVER THERAPY

The regeneration of hemoglobin is slower than the regeneration of red cells.

\section{Hemoglobin}

Total circulating hemoglobin was extremely low during the severe stages of anemia, having been, on an average, 238 and 202 grams, in contrast to average normal amounts of 877 and 540 grams, in the males and females respectively. After recovery, total circulating hemoglobin had increased over initial levels on an average of 519 grams, or about 220 per cent in the males and 411 grams or about 200 per cent in the females. In terms of percentage deviation from normal the course of the total circulating hemoglobin bore a linear relationship to the increase in red cell count as shown in Figure 3, but while the curve of increase in total circulating hemoglobin paralleled the corresponding curve of circulating red cell volume, it definitely lagged behind during the early and middle stages of therapy.
In Table II are shown changes in mean corpuscular volume and hemoglobin, mean corpuscular hemoglobin concentration, and in the volume, color and saturation indices. The averages of volume and hemoglobin corpuscular measurements with reference to the course of the total circulating red cell volume as the red blood cell count rose to 5 million cells are shown in Figure 4.

\section{Venous pressure and circulation time}

Venous pressures varied considerably during the course of treatment, having a tendency to be in the high range of normal during the anemic stages and to fall slightly with clinical improvement as shown in Figure 5. However, there were considerable individual variations, ranging from 30 to $110 \mathrm{~mm}$. of water, in initial determina- 
TABLE II

Individual cell volume and hemoglobin measurements and volume, color, and saturation indices in 10 cases of pernicious anemia

\begin{tabular}{|c|c|c|c|c|c|c|c|c|c|}
\hline $\begin{array}{c}\text { Case } \\
\text { num- } \\
\text { ber }\end{array}$ & $\begin{array}{l}\text { Red } \\
\text { blood } \\
\text { cells }\end{array}$ & $\begin{array}{l}\text { Hemo- } \\
\text { globin }\end{array}$ & $\begin{array}{c}\text { Hema- } \\
\text { tocrit }\end{array}$ & $\begin{array}{c}\text { Mean } \\
\text { corpus } \\
\text { cular } \\
\text { volume }\end{array}$ & $\begin{array}{c}\text { Mean } \\
\text { corpus } \\
\text { cular } \\
\text { bemo- } \\
\text { globin }\end{array}$ & $\begin{array}{l}\text { Mean } \\
\text { corpus } \\
\text { cular } \\
\text { hemo- } \\
\text { globin } \\
\text { concen- } \\
\text { tration }\end{array}$ & $\begin{array}{c}\text { Vol- } \\
\text { ume } \\
\text { index }\end{array}$ & $\begin{array}{l}\text { Color } \\
\text { index }\end{array}$ & $\begin{array}{l}\text { Satu- } \\
\text { ration } \\
\text { index }\end{array}$ \\
\hline & $\begin{array}{c}\text { millions } \\
\text { per } \\
c . \mathrm{mm} .\end{array}$ & $\begin{array}{c}\text { grams } \\
\text { per } \\
100 \mathrm{cc} .\end{array}$ & $\begin{array}{l}\text { per cent } \\
\text { of celle }\end{array}$ & $\begin{array}{c}\text { cubic } \\
\text { microns }\end{array}$ & $\begin{array}{l}\text { micro- } \\
\text { grams }\end{array}$ & $\begin{array}{c}\text { grams } \\
\text { per } \\
100 \propto c .\end{array}$ & & & \\
\hline $\begin{array}{l}165 \mathrm{~A} \\
165 \mathrm{~B} \\
165 \mathrm{C}\end{array}$ & $\begin{array}{l}1.67 \\
2.60 \\
5.16\end{array}$ & $\begin{array}{r}4.47 \\
7.10 \\
12.42\end{array}$ & $\begin{array}{l}13.8 \\
28.6 \\
41.6\end{array}$ & $\begin{array}{r}82.7 \\
110.0 \\
80.6\end{array}$ & & & $\begin{array}{l}1.035 \\
1.405 \\
1.005\end{array}$ & $\left|\begin{array}{l|}0.921 \\
0.932 \\
0.822\end{array}\right|$ & $\begin{array}{l}0.890 \\
0.663 \\
0.819\end{array}$ \\
\hline $\begin{array}{l}90 \mathrm{~A} \\
90 \mathrm{~B} \\
90 \mathrm{C}\end{array}$ & $\begin{array}{l}2.26 \\
3.74 \\
5.33\end{array}$ & $\begin{array}{r}6.90 \\
9.80 \\
14.63\end{array}$ & & $\begin{array}{r}117.5 \\
97.8 \\
77.8\end{array}$ & & & $\begin{array}{l}1.475 \\
1.220 \\
0.970\end{array}$ & $\begin{array}{l}1.042 \\
0.897 \\
0.940\end{array}$ & \\
\hline $\begin{array}{l}191 \mathrm{~A} \\
191 \mathrm{~B} \\
191 \mathrm{C}\end{array}$ & $\begin{array}{l}1.22 \\
3.38 \\
5.50\end{array}$ & $\begin{array}{r}5.52 \\
10.25 \\
13.05\end{array}$ & & $\begin{array}{r}125.0 \\
98.8 \\
72.3\end{array}$ & & & $\begin{array}{l}1.605 \\
1.215 \\
0.887\end{array}$ & $\begin{array}{l}1.610 \\
1.050 \\
0.820\end{array}$ & \\
\hline $6 \mathrm{BA}$ & $\begin{array}{l}1.04 \\
5.17\end{array}$ & $\begin{array}{r}4.83 \\
15.09\end{array}$ & & $\begin{array}{r}146.0 \\
83.2\end{array}$ & & & $\begin{array}{l}1.805 \\
1.060\end{array}$ & $\left|\begin{array}{l|}1.585 \\
0.995\end{array}\right|$ & $\begin{array}{l}0.878 \\
0.938\end{array}$ \\
\hline $\begin{array}{l}8 \mathrm{~A} \\
8 \mathrm{~B}\end{array}$ & $\begin{array}{l}1.70 \\
5.10\end{array}$ & $\begin{array}{r}5.60 \\
15.95\end{array}$ & & $\begin{array}{l}95.3 \\
80.1\end{array}$ & $\begin{array}{l}32.9 \\
32.7\end{array}$ & & $\begin{array}{l}1.170 \\
0.987\end{array}$ & \begin{tabular}{|l|}
1.135 \\
1.082 \\
\end{tabular} & $\begin{array}{l}0.970 \\
1.095\end{array}$ \\
\hline $\begin{array}{l}50 \mathrm{~A} \\
50 \mathrm{~B} \\
50 \mathrm{C} \\
50 \mathrm{D}\end{array}$ & $\begin{array}{l}1.56 \\
2.59 \\
3.45 \\
5.14\end{array}$ & $\begin{array}{r}7.59 \\
9.38 \\
12.02 \\
16.18\end{array}$ & & $\begin{array}{r}110.2 \\
100.3 \\
100.1 \\
79.3\end{array}$ & $\begin{array}{l}48.8 \\
36.2 \\
34.9 \\
31.4\end{array}$ & & $\begin{array}{l}1.360 \\
1.260 \\
1.245 \\
0.972\end{array}$ & \begin{tabular}{|l|}
1.685 \\
1.250 \\
1.205 \\
1.090
\end{tabular} & $\begin{array}{l}1.240 \\
0.993 \\
0.957 \\
1.120\end{array}$ \\
\hline $\begin{array}{l}271 \mathrm{~A} \\
271 \mathrm{~B} \\
271 \mathrm{C}\end{array}$ & $\begin{array}{l}2.17 \\
2.84 \\
3.80\end{array}$ & $\begin{array}{r}9.50 \\
11.40 \\
11.25\end{array}$ & $\begin{array}{l}20.5 \\
24.8 \\
35.9\end{array}$ & $\begin{array}{l}94.4 \\
87.2 \\
77.2\end{array}$ & & & $\begin{array}{l}1.175 \\
1.085 \\
1.175\end{array}$ & \begin{tabular}{|l|}
1.495 \\
1.372 \\
1.030 \\
\end{tabular} & $\begin{array}{l}1.272 \\
1.265 \\
0.877\end{array}$ \\
\hline $\begin{array}{l}33 \mathrm{~A} \\
33 \mathrm{~B} \\
33 \mathrm{C} \\
3 \mathrm{D}\end{array}$ & $\begin{array}{l}1.05 \\
1.97 \\
3.07 \\
4.67\end{array}$ & $\begin{array}{r}3.73 \\
5.58 \\
8.56 \\
15.00\end{array}$ & $\begin{array}{l}11.4 \\
19.4 \\
29.2 \\
39.1\end{array}$ & $\begin{array}{r}108.5 \\
98.3 \\
95.2 \\
83.3\end{array}$ & $\begin{array}{l}35.7 \\
28.3 \\
27.9 \\
32.1\end{array}$ & & $\begin{array}{l}1.343 \\
1.230 \\
1.185 \\
1.035\end{array}$ & $\begin{array}{l}1.215 \\
0.972 \\
0.953 \\
1.105\end{array}$ & \begin{tabular}{|l|}
0.905 \\
0.790 \\
0.803 \\
1.068
\end{tabular} \\
\hline $\begin{array}{l}29 \mathrm{~A} \\
29 \mathrm{~B}\end{array}$ & $\begin{array}{l}0.83 \\
2.25 \\
3.32\end{array}$ & $\begin{array}{r}4.28 \\
7.39 \\
11.55\end{array}$ & & $\begin{array}{r}166.2 \\
101.5 \\
97.6\end{array}$ & & & $\begin{array}{l}2.050 \\
1.255 \\
1.200\end{array}$ & $\begin{array}{l}1.785 \\
1.138 \\
1.205\end{array}$ & $\begin{array}{l}0.871 \\
0.907 \\
1.005\end{array}$ \\
\hline $2 \mathrm{~A}$ & $\begin{array}{l}1.38 \\
3.07 \\
5.08\end{array}$ & & & $\begin{array}{r}130.0 \\
114.0 \\
80.3\end{array}$ & $\begin{array}{l}38.1 \\
39.4 \\
31.6\end{array}$ & $\begin{array}{l}29.4 \\
34.6 \\
39.3\end{array}$ & $\begin{array}{l}1.615 \\
1.420 \\
1.000\end{array}$ & $\begin{array}{l}1.300 \\
1.350 \\
1.077\end{array}$ & $\begin{array}{l}0.805 \\
0.950 \\
1.077\end{array}$ \\
\hline
\end{tabular}

tions of venous pressure, and in the direction and degree of changes observed during therapy.

Circulation time was definitely decreased in the anemic stages of the disease, as shown in Figure 5, and, on the average, increased during therapy in a linear relationship to the increase in the red cell count, returning to normal when recovery was complete.

\section{DISCUSSION}

In contrast to the conflicting observations reported in the literature the findings herein presented exhibit a striking consistency in the degree of abnormality of plasma, red blood cell, and total blood volume during the severe stages of pernicious anemia and in the behavior of the component elements of the blood volume both as to absolute values and relative changes during recovery on liver extract therapy. Pernicious anemia is char- acterized by a hydremic hypovolemia, and the degree of hydremia and hypovolemia and of reduction from normal in the circulating red cell volume and total hemoglobin is in direct relationship to the severity of the disease as evidenced by the levels of the red cell count or hematocrit, and hemoglobin.

A somewhat different situation prevails in the hypochromic anemias. In a group of 31 patients with secondary anemias, 9 of whom had an anemia due to chronic blood loss, 1 due to acute nephritis, 3 due to chronic vascular nephritis, 9 due to chronic glomerular nephritis and 9 due to so-called " nephrosis," the author has found no definite relationship between the degree of deviation from normal total blood volume and the red blood cell count level, about one-third of the group having total blood volumes from 0 to 15 per cent above and the remainder having total blood volumes from 0 to 18 per cent below normal, the average value for the entire group being only slightly below normal. However, all of these patients had subnormal circulating red blood cell volumes, and, in resemblance to the group of patients with pernicious anemia herein studied, the relationship of the percentage deviation from normal circulating red cell volume to the red blood cell count was such that the slope of the curve of this deviation was the same in both groups. It would seem that the patient with pernicious anemia, in contrast to the patient with a secondary anemia, has definite limits to the extent to which total blood volume, diminished by a reduction in the circulating red cell volume, can be augmented by blood hydration. Other than being possibly due to chronic dehydration, the cause of this difference is not clear and merits further investigation.

The marked reduction in total circulating hemoglobin observed by other workers is confirmed by this study. The patients in the group studied, when they first came under medical observation, had on an average only one-third of their normal total circulating hemoglobin, and yet none of them presented symptoms of marked respiratory distress. A discussion of the "compensatory" mechanism by which patients with pernicious anemia carry on fairly adequate respiratory function is beyond the scope of this paper. That the efficiency of the lowered oxygen capacity of the blood is increased is a widely accepted belief. The 


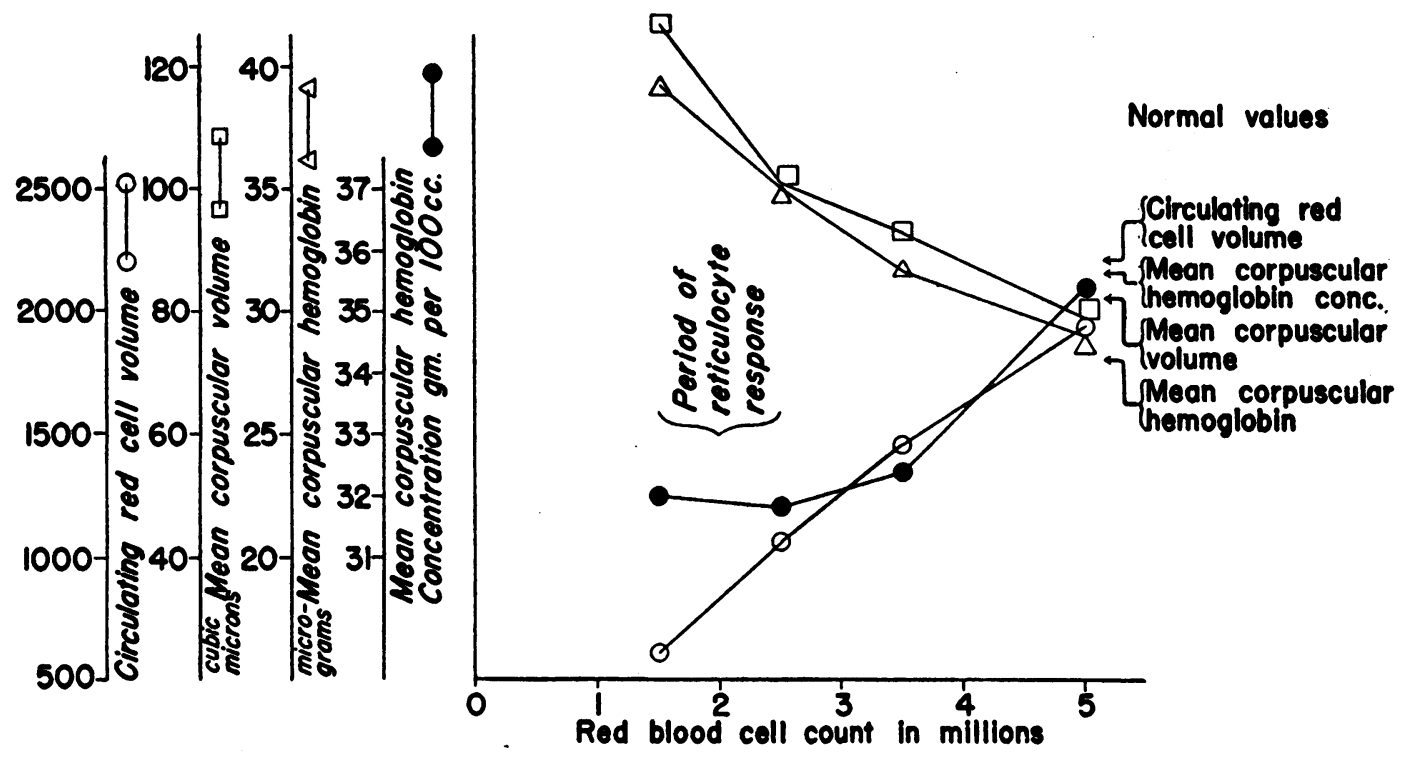

Fig. 4. Changes in the Size and Hemoglobin Content and Concentration of the Individual Red Cell, and in the Saturation Index during Recovery from Pernicious Anemia on Liver Therapy, Shown in Relation to the Increase in the Circulating Red Ceml Volume

The lines represent average values for the group of 10 cases. While the individual cell is larger and contains more hemoglobin than a normal red cell, the total red cell mass, in comparison to normal, is definitely deficient in hemoglobin, and this deficiency is not fully met until recovery is almost complete.

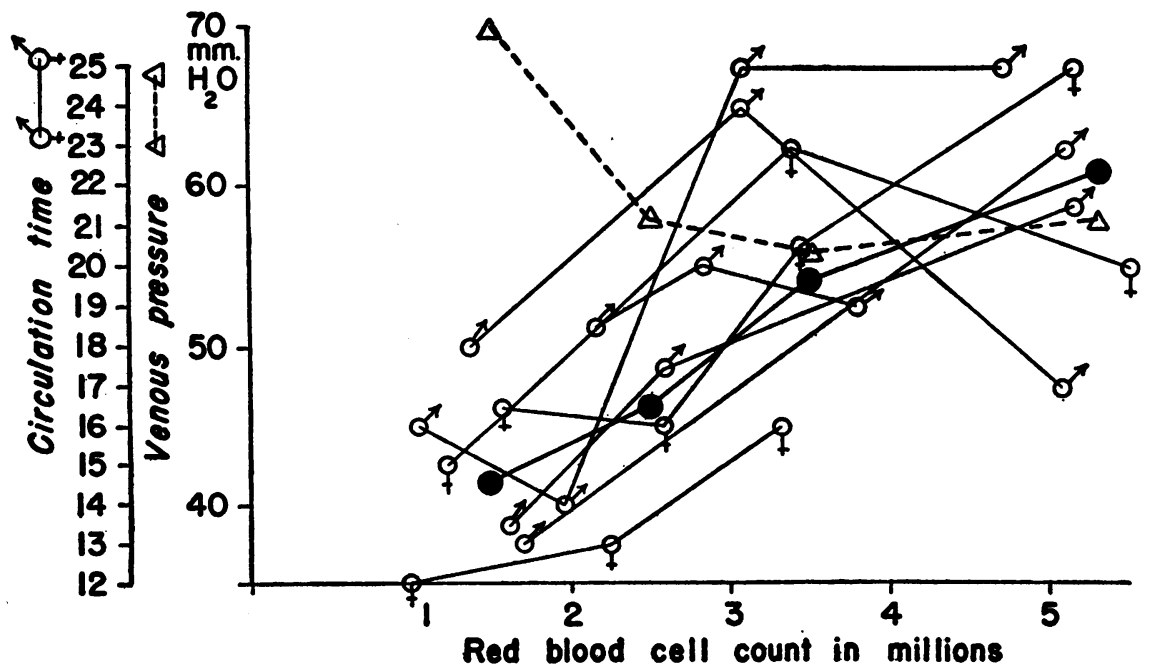

Fig. 5. Increase in the Circulation time as the Red Cell Count Rises

The line connecting the black circles is the average trend of circulation time, that connecting the triangles the average trend of venous pressure. The changes in venous pressure are of no clinical significance. 
finding of an increased speed of blood flow in this group of patients (see Figure 5) is in keeping with the observation of Blumgart, et al. (16). Better oxygen utilization, as evidenced by an increase in the arteriovenous difference in oxygen content of the blood, has been demonstrated by Henderson (17).

In this series of cases the size, hemoglobin content, and concentration of the individual red cell and the volume, color, and saturation indices are in keeping with those reported in the literature. Thus, Wintrobe (18) found an average mean corpuscular volume of 116 cubic microns in patients with pernicious anemia with erythrocyte counts ranging from 0.59 to 4.03 million, in comparison to a normal range of from 70 to 98 cubic microns (19), and Haden (20) found the mean corpuscular volume in pernicious anemia to range from 108 to 163 cubic microns. These same authors found the mean corpuscular hemoglobin to average 39 and 40.1 micrograms, both values being well above normal. The volume index has been found to be greater than 1 by Capps (21) and Haden (22) and color index greater than 1 by Goldhamer, et al. (23). Yet, Haden (24) reported an average saturation index of 0.92 in 50 cases, indicating that the red cells did not contain their maximum capacity of hemoglobin, and certainly were not supersaturated, as the color index would suggest.

The data illustrated in Figure 4 are of interest in this connection. Both mean corpuscular volume and hemoglobin are definitely above normal in the severe stages of anemia and decrease, approaching normal, as the red cell count rises. Mean corpuscular hemoglobin concentration is an expression of the hemoglobin content of a unit mass, not of whole blood but of red cells, and this value is decidedly below normal in the severe stages, approaching normal only after the red cell count has reached about 3 million.

It is, therefore, apparent that in pernicious anemia, while the individual cell is larger and contains more hemoglobin than a normal red cell, the total red cell mass in comparison to an equal mass of normal red cells is definitely deficient in hemoglobin, and that, on liver therapy alone, this deficiency is not met until recovery is almost complete. It is of interest that this failure of the total red cell mass to attain its normal complement of hemoglobin occurs at a time, following effective liver therapy, when red cells are being rapidly regenerated. It cannot be entirely accounted for by decreases in the mean corpuscular volume and hemoglobin, since, as shown in Figure 3, in terms of percentage of normal, total hemoglobin is less than total circulating red cell volume until the erythrocyte count reaches normal.

Two explanations of this difference in rate of regeneration of red cells and hemoglobin suggest themselves. The formation of hemoglobin may be slower than the development of new red cells and hence inevitably proceed at a slower rate. The bone marrow of pernicious anemia is hyperplastic, and it is characteristic that the erythrocyte is arrested in its development in this disease. The effective principle of liver is thought to check this developmental inhibition, so that a large quantity of dormant cells rapidly mature and are liberated early in the course of treatment.

Another possibility is that a true iron deficiency may exist in the severe stages of the disease, so that a real shortage of hemoglobin building substances may delay the synthesis of hemoglobin. Murphy, Lynch, and Howard (25) concluded that during a relapse the "iron index" (whole blood iron divided by the red cell count in millions) was above normal, approaching normal during recovery. Reich and Tiedemann (26) also found a normal "iron volume index" in pernicious anemia but regarded this as evidence that iron therapy was of no value in this disease since "the red cells are already saturated with iron." Moore and Doan (27), however, clearly showed that the plasma iron, which they considered to be iron in the form most available for hemoglobin synthesis, while normal or above during a relapse, fell rapidly to subnormal levels on the initiation of liver therapy and remained low throughout the period of reticulocyte response and until the erythrocyte count had reached between 3 and 4 million cells, after which it gradually rose. Thus, while the red cells present in the blood during a relapse probably have a normal complement of iron the lowering of the plasma iron accompanying the tremendous new production of hemoglobin during treatment is direct evidence of a depletion of stored iron in the severe stages of the disease. It is possible that the patient with pernicious anemia should receive therapy directed to restoring an iron deficit in addition to treatment with 
the effective substance contained in liver. Murphy (28) has shown that the response of a group of patients with pernicious anemia treated with iron supplementing liver extract was definitely better than that of a control group receiving liver therapy alone.

The immediate increase in reticulocytes characteristic of liver therapy in pernicious anemia has led to the practice of using the reticulocyte response as a basis for judging the potency of any liver preparation. That the height of the rise of the reticulocytes varies with the initial level of red blood cells when liver is given by mouth was pointed out by Minot, Cohn, Murphy, and Lawson (29).
Bethell and Goldhamer (30) described a similar characteristic of the reticulocyte response in 39 patients receiving a single dose of liver extract (an amount derived from 100 grams of liver) intravenously. In a larger series of cases given liver extract intraumuscularly at intervals of from 1 to 7 days, the totaling amount averaging about 1 U.S.P. unit a day, Isaacs and Friedman (31) confirmed these findings. Based on this characteristic the Council on Pharmacy and Chemistry of the American Medical Association has adopted a standard test curve (32) for evaluating the potency of liver extracts to be used in the treatment of pernicious anemia.

In Table III is shown the initial reticulocyte and

TABLE III

Increases in the reticulocyte and red blood cell counts in 10 patients following intramuscular liver extract therapy

\begin{tabular}{|c|c|c|c|c|c|c|c|c|c|c|c|c|c|c|c|}
\hline \multirow{2}{*}{ Case number } & \multirow{2}{*}{$\begin{array}{l}\text { Total } \\
\text { amount } \\
\text { of liver } \\
\text { extract }\end{array}$} & \multirow{2}{*}{$\begin{array}{l}\text { Ten } \\
\text { daily } \\
\text { equal } \\
\text { doses }\end{array}$} & \multirow{2}{*}{$\begin{array}{c}\text { Single } \\
\text { dose }\end{array}$} & & \multirow{2}{*}{$\begin{array}{l}\text { Before } \\
\text { treat- } \\
\text { ment }\end{array}$} & \multicolumn{10}{|c|}{ Days after beginning therapy } \\
\hline & & & & & & 1 & 2 & 3 & 4 & 5 & 6 & 7 & 8 & 9 & 10 \\
\hline \multirow[t]{2}{*}{165} & \multirow[t]{2}{*}{$\begin{array}{c}\text { U.S.P. } \\
\text { units } \\
50.0\end{array}$} & & \multirow[t]{2}{*}{$\mathbf{x}$} & $\mathbf{R}^{*}$ & & 2.0 & 8.0 & 15.0 & 29.1 & 49.7 & 40.7 & 28.3 & 14.0 & 2.6 & \\
\hline & & & & $\mathrm{C} \dagger$ & 1.7 & & & & & & 2.4 & & & & \\
\hline \multirow[t]{2}{*}{190} & \multirow[t]{2}{*}{7.5} & \multirow[t]{2}{*}{$\mathbf{x}$} & & $\mathbf{R}$ & 1.0 & & 2.0 & 2.0 & 1.6 & 1.2 & 2.8 & 9.2 & 10.6 & 4.4 & 3.2 \\
\hline & & & & C & 2.3 & & & & 2.5 & & & & & 3.0 & \\
\hline \multirow[t]{2}{*}{191} & \multirow[t]{2}{*}{7.5} & \multirow[t]{2}{*}{$\mathbf{x}$} & & $\mathbf{R}$ & & 5.6 & 4.8 & 5.8 & 5.4 & 6.0 & 10.4 & 15.5 & 14.0 & 15.6 & 10.4 \\
\hline & & & & $\mathrm{C}$ & 1.2 & & & & & & & 1.8 & & & 1.9 \\
\hline \multirow[t]{2}{*}{216} & \multirow[t]{2}{*}{60.0} & & \multirow[t]{2}{*}{$\mathbf{x}$} & $\mathbf{R}$ & 1.8 & & 2.6 & 1.6 & 16.0 & 17.0 & 24.5 & 24.1 & 12.2 & 11.2 & 9.6 \\
\hline & & & & C & 1.0 & & & & 1.1 & & & 2.4 & & & 2.4 \\
\hline \multirow[t]{2}{*}{218} & \multirow[t]{2}{*}{7.5} & & \multirow[t]{2}{*}{$\mathbf{x}$} & $\mathbf{R}$ & 2.8 & 2.8 & 6.2 & 6.4 & 13.8 & 18.2 & 21.0 & 14.6 & & & \\
\hline & & & & C & 1.3 & & & & 1.6 & & & 1.7 & & & \\
\hline \multirow[t]{2}{*}{250} & \multirow[t]{2}{*}{7.5} & \multirow[t]{2}{*}{$\mathbf{x}$} & & $\mathbf{R}$ & 1.2 & 1.2 & 1.6 & 2.2 & 4.4 & & 8.6 & 12.0 & 16.0 & 18.6 & 9.4 \\
\hline & & & & C & 1.6 & & & & $1: 7$ & & & & 1.8 & 1.8 & \\
\hline \multirow[t]{2}{*}{271} & \multirow[t]{2}{*}{7.5} & \multirow[t]{2}{*}{$\mathbf{x}$} & & $\mathbf{R}$ & 2.0 & 3.3 & 2.8 & & 4.0 & 6.0 & 8.4 & 10.6 & 17.8 & 10.2 & 8.7 \\
\hline & & & & C & 1.6 & & & & 1.9 & & & 2.2 & & 2.0 & 2.5 \\
\hline \multirow[t]{2}{*}{283} & \multirow[t]{2}{*}{40.0} & & $x$ & $\mathbf{R}$ & 0.4 & 0.4 & 0.7 & 12.6 & 30.4 & 36.2 & 26.8 & 33.0 & & & \\
\hline & & & & C & 1.1 & & & & & & & 2.0 & & & \\
\hline 329 & 10.0 & $\mathbf{x}$ & & $\mathbf{R}$ & 1.8 & 2.1 & 3.1 & 4.5 & 6.1 & 13.1 & 23.0 & 33.0 & 26.9 & 21.9 & 22.0 \\
\hline & & & & C & 1.0 & & & & & & & & 1.5 & & $\cdot$ \\
\hline 332 & 10.0 & $\mathbf{x}$ & & $\mathbf{R}$ & 0.3 & 0.4 & 0.6 & 1.6 & 2.0 & 4.5 & 7.9 & 12.7 & 28.0 & 27.0 & 29.6 \\
\hline & & & & C & 1.4 & & & & & & & & 2.3 & & \\
\hline
\end{tabular}

* Reticulocyte count in per cent of red blood cell count.

† Red blood cell count in millions per c. $\mathrm{mm}$. 
red blood cell counts and the course of these determinations during the first 10 days of treatment in the patients in this series with reference to the number of U. S. P. units administered and the size and frequency of dosage given. In Figure 6 the reticulocyte level at the time of the maximum response is shown in comparison to the expected maximum based on the standard test curve of the American Medical Association and in addition to the absolute increase in red cell count, and the percentage of the deficit in red blood cell count, total circulating hemoglobin, and circulating red blood cell volume present at the beginning of therapy regenerated in 10 days.

In the 6 cases given small daily doses the reticulocyte response was satisfactory in all but Cases 191 and 329 and yet the production of new cells and hemoglobin after 10 days of treatment in these cases was above the average of the entire group, and on continued treatment for 28 days with the same extract initially used (see Figure 1) the red cell count was definitely above the average for the entire group.

On the other hand in Cases 250 and 271 new production of red cells and hemoglobin was definitely below average both at the 10 and 28-day periods in spite of a reticulocyte response that was well up to standard test requirements.

Thus in 4 of the 6 cases receiving 10 daily doses the conformance of the reticulocyte count to the standard test curve bore no constant relationship to the regeneration of blood either during the reticulocyte rise or during a subsequent period of about 3 weeks thereafter.

A comparison of the 4 cases given large single doses as initial treatment is of interest. In all these cases the reticulocyte response was prompt and while it cannot be directly referred to the standard test curve (initial red cell counts being considered) was on the whole higher than that of the group receiving 10 daily divided doses (see Table III). Yet the production of red cells and hemoglobin, in terms of deficit regenerated was below average at 10 days in Cases 216 and 283, and about average in Cases 165 and 218. Eighteen days later, during which interval further large doses were given to 3 cases (Cases 265, 216, and 283), the increase in red cells was only a little better than the average of the group receiving divided doses.
It would appear from the data presented that the reticulocyte response experienced by these patients did not bear a constant relationship to the degree of improvement in their blood as a whole either during the phase of reticulocyte activity or subsequent thereto. It should also be stated that the reticulocyte response is transient and cannot serve as an index of the therapeutic effectiveness of a liver preparation throughout the entire course of recovery or during maintenance therapy.

The striking linear relationship of the red blood cell count and hematocrit to the percentage of normal circulating red blood cell volume and total hemoglobin respectively observed in this study indicates that, for purposes of following the clinical course of the patient, the red cell count or hematocrit are good indicators of the degree of return to normal levels of the circulating red cell volume, and the hemoglobin determination is a good indicator of the degree of the return to normal of the total hemoglobin content of the blood. It is suggested that a useful interpretation of increases in red cell count and hemoglobin is in terms of the percentage of the deficit existing before the beginning of treatment regenerated.

These findings perhaps suggest the wisdom of evaluating the potency of a liver preparation upon the course of red cell count and hemoglobin during the entire period of recovery, in addition to the conformance of the transient reticulocyte rise to a standard test curve.

\section{CONCLUSIONS}

1. Pernicious anemia is characterized by a hydremic hypovolemia in the severe stages. In the group of 10 cases studied the average plasma volume was 30 per cent above, circulating red blood cell volume 68 per cent below, total blood volume 14 per cent below, and total hemoglobin 70 per cent below normal, at a red blood cell level of 1.5 million.

2. Under treatment with a potent liver extract, plasma, circulating red blood cell, total blood volume, and total circulating hemoglobin returned to within normal limits when the red cell count reached normal, and these blood components changed in a linear relationship to the change in the red cell count and hematocrit.

3. In the severe stages of anemia, although the individual red cells were larger than normal and 
Case No.
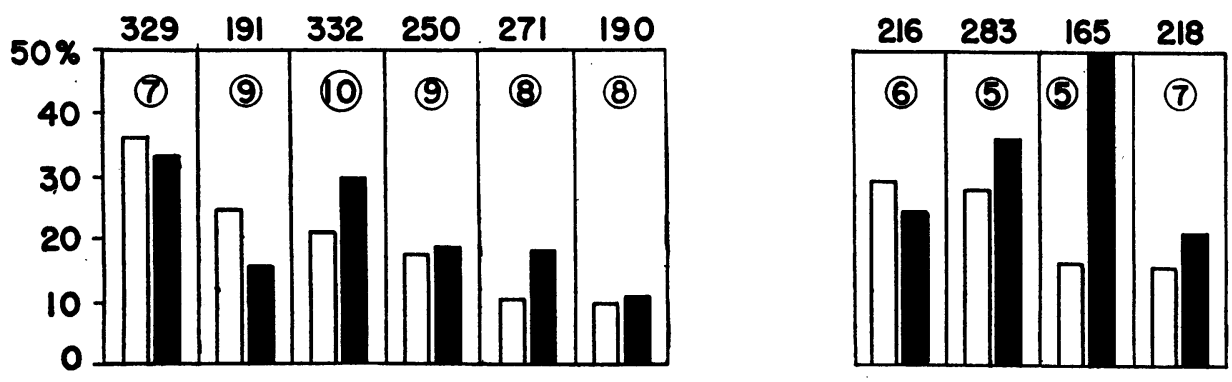

Reticulocyte response

$\square$ A.M.A. testing requirement

Count of peak of rise on day shown in circle

\begin{tabular}{|c|c|c|c|c|c|}
\hline 10 & 7.5 & 10 & 7.5 & 7.5 & 7.5 \\
\hline
\end{tabular}

\begin{tabular}{|l|l|l|l|}
\hline 60 & 40 & 50 & 7.5 \\
\hline
\end{tabular}

Amount of Liver Extract given - U.S.P. Units
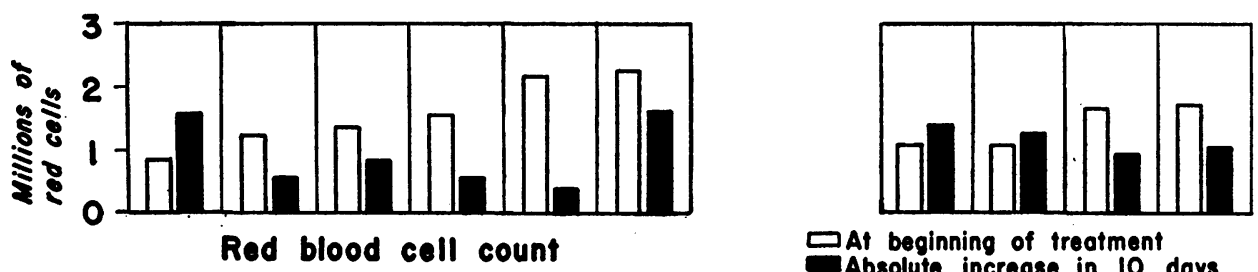

Red blood cell count

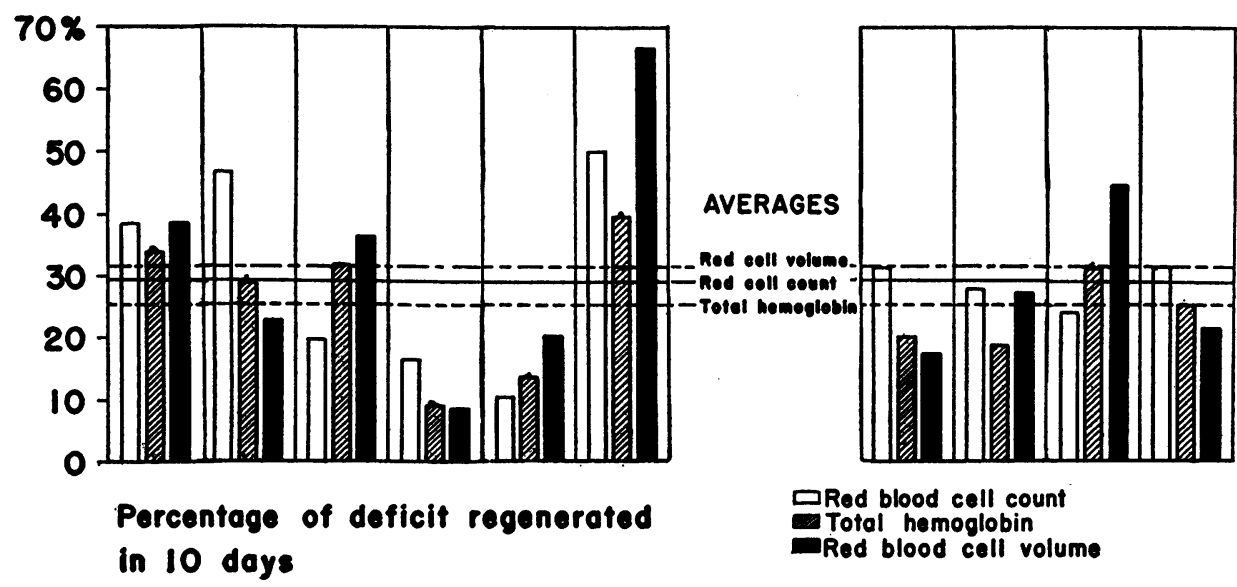

Fig. 6. Regeneration of Blood Following Intramuscular Liver Therapy

Cases given 10 daily doses of concentrate are grouped at the left of the chart, those given single large doses at the right. The relationship of the conformance of the reticulocyte maximum to the regeneration of the blood as a whole in terms of the percentage of the deficit in red cells and hemoglobin present at the beginning of therapy regenerated in 10 days is discussed in the text. 
contained more hemoglobin than a normal cell, the hemoglobin content of a unit mass of red cells was less than that of an equal unit mass of normal red cells. There is, in pernicious anemia, a relative as well as absolute deficiency in hemoglobin.

4. In the cases studied, the magnitude of the reticulocyte response following treatment with a potent extract bore no constant relation to the concomitant or subsequent improvement in the blood in terms of the percentage of regeneration of the deficit in circulating red cell volume or total hemoglobin. It is suggested that the present practice of evaluating the potency of any liver preparation on the basis of the conformance of the reticulocyte response to a standard test curve might well be supplemented by consideration of the course of the red blood cell count and hemoglobin over the entire period of recovery.

The author wishes to thank Dr. William P. Murphy for his interest and encouragement in this study and Miss Isobel Howard for her painstaking technical assistance.

\section{BIBLIOGRAPHY}

1. Bock, A. V., The constancy of the volume of the blood plasma. Arch. Int. Med., 1921, 27, 83.

2. Denny, G. P., The blood volume in pernicious anemia. Arch. Int. Med., 1921, 27, 38.

3. Murphy W. P., Monroe, R., and Fitz, R., Changes in the composition of the blood in pernicious anemia. J. A. M. A., 1927, 88, 1209.

4. Keith, N. M., The total circulating blood and plasma in cases of chronic anemia. Am. J. M. Sc., 1923, $165,174$.

5. Rusynak, S., Untersuchungen zur Frage der gesamt Blutmenge des Menschen unter normalen und pathologische Verhaltnissen. Deutsches Arch. f. klin. Med., 1927, 67, 186.

6. De Wesselow, O. L. V., and Bamforth, J., The blood and plasma volumes in pernicious anemia. Lancet, 1928, 1, 1016.

7. Smith, J. L., The blood in disease. Tr. Path. Soc. London, 1900, 51, 311.

8. Hölboll, S. A., Untersuchungen über den Einfluss der Lebertherapie auf die grösse der Blutmenge bei Patienten mit Anämia Perniciosa. Acta med. Scandinav., 1929, Supp. 34, 90.

9. Gregersen, M. I., Gibson, J. G., and Stead, E. A., Plasma volume determination with dyes; errors in colorimetry; use of the blue dye T-1824. Am. J. Physiol., 1935, 113, 54.

10. Gibson, J. G., 2d, and Evans, W. A., Jr., Clinical studies of the blood volume. I. Clinical application of a method employing the blue azo dye "Evans Blue" and the spectrophotometer. J. Clin. Invest., 1937, 16, 301.
11. Evans, Wm., Venous pressure. New England J. Med., 1932, 207, 1934.

12. Winternitz, M., Deutsch, J., and Brüll, Z., Eine klinisch brauchbare Bestimmungsmethode der Blutumlaufszeit mittels Decholininjektion. Med. Klin., 1931, 27, 986.

13. Osgood, E. E., and Haskins, H. B., A new permanent standard for estimation of hemoglobin by the acid hematin method. J. Biol. Chem., 1923, 57, 107.

14. Gibson, J. G., 2d, and Evans, W. A., Jr., Clinical studies of the blood volume. II. The relation of plasma and total blood volume to venous pressure, blood velocity rate, physical measurements, age and sex in ninety normal humans. J. Clin. Invest., 1937, 16, 317.

15. Murphy, W. P., and Howard, I. M., The iron content of crystals of hemoglobin prepared from human blood. (In preparation.)

16. Blumgart, H. L., Gargill, S. L., and Gilligan, D. R., Studies on the velocity of blood flow. XV. The velocity of blood flow and other aspects of the circulation in patients with "primary" and secondary anemia and in two patients with polycythemia vera. J. Clin. Invest., 1930, 9, 679.

17. Henderson, J. L., Blood. A Study in General Physiology. Yale University Press, New Haven, 1928.

18. Wintrobe, M. M., The hemoglobin content, volume and thickness of the red blood corpuscles in pernicious anemia and sprue, and the changes associated with liver therapy. Am. J. M. Sc., 1931, $181,217$.

19. Wintrobe, M. M., The volume and hemoglobin content of the red blood corpuscle; simple method of calculation, normal findings and value of such calculations in the anemias. Am. J. M. Sc., 1929, 177, 513.

20. Haden, R. L., Accurate criteria for differentiating anemias. Arch. Int. Med., 1923, 31, 765.

21. Capps, J. A., A study of volume index. Observations on the volume of erythrocytes in various diseased conditions. J. Med. Research, 1903, 10, 367.

22. Haden, R. L., The volume and hemoglobin content of the erythrocytes in health and disease. Folia haemat., 1925, 31, 113.

23. Goldhamer, S. M., Fritzell, A., Davidson, E., and Steen, C., The clinical value of the uncorrected color index and of cell size in pernicious anemia. Am. J. M. Sc., 1932, 184, 165.

24. Haden, R. L., The value of volume index in the diagnosis of pernicious anemia. J. A. M. A., 1924, 83, 671.

25. Murphy, W. P., Lynch, R., and Howard I., The value of determinations of the iron content of the whole blood. Arch. Int. Med., 1931, 47, 883.

26. Reich, C., and Tiedemann, V. G., A study of "Iron volume index" of the blood and its significance in the treatment of anemia. Am. J. M. Sc., 1932, $184,637$. 
27. Moore, C., and Doan, C. A., The mechanism of postsplenectomy erythroid reëquilibration. J. A. M. A. (Proc. Cent. Soc. Clin. Res.), 1936, 106, 325.

28. Murphy, W. P., Production of reticulocytes, erythrocytes and hemoglobin in anemia. Arch. Int. Med., 1933, 52, 829.

29. Minot, G. R., Cohn, E. J., Murphy, W. P., and Lawson, $H$. A., Treatment of pernicious anemia with liver extract. Am. J. M. Sc,. 1928, 175, 599.

30. Bethell, F. H., and Goldhamer, S. M., Standards for maximum reticulocyte values following ventriculin and intravenous liver extract therapy in pernicious anemia. Am. J. M. Sc., 1933, 186, 480.

31. Isaacs, R., and Friedman, A., Standards for maximum reticulocyte percentage after intramuscular liver therapy in pernicious anemia. Am. J. M. Sc., 1938, 196, 718.

32. Reports of the Council on Pharmacy and Chemistry. Standardization and labelling of liver and stomach preparations for use in the treatment of pernicious anemia. J. A. M. A., 1935, 105, 1269. 